\title{
Medicinal plants used by the indigenous Ati tribe in Tobias Fornier, Antique, Philippines
}

\author{
CECILIA S. CORDERO ${ }^{1,2, \vartheta}$, GRECEBIO JONATHAN D. ALEJANDRO ${ }^{1,3}$ \\ ${ }^{1}$ The Graduate School, University of Santo Tomas. España Boulevard, 1015 Manila, Philippines. \\ Tel.+63-2-34061611, `email: cecilia.cordero@sdca.edu.ph \\ ${ }^{2}$ Biology Department, School of Health Science Professions, St. Dominic College of Asia. Aguinaldo Highway, 4102 City of Bacoor, Cavite, Philippines \\ ${ }^{3}$ College of Science and Research Center for the Natural and Applied Sciences, University of Santo Tomas. España Boulevard, 1015 Manila, Philippines
}

Manuscript received: 30 November 2020. Revision accepted: 5 January 2021

\begin{abstract}
Cordero CS, Alejandro GJD. 2021. Medicinal plants used by the indigenous Ati tribe in Tobias Fornier, Antique, Philippines. Biodiversitas 22: 521-536. This study documented the medicinal plants used by the indigenous Ati tribe in Sitio Pantad, Brgy. Igcalawagan, Tobias Fornier, Antique. Semi-structured interviews were conducted with the tribal chieftain, council of elders, herb doctors, and other members of the tribe who have indigenous knowledge of using medicinal plants in traditional medicine. The Use Value, Informant Consensus Factor, and Fidelity Level were used to determine the plants' importance. A total of 108 plant species distributed in 97 genera and 44 families were used by the Ati to treat 67 diseases in 12 categories. The family Fabaceae was best represented with 15 species, followed by Lamiaceae with 12 species, and Asteraceae, Euphorbiaceae, and Poaceae with 5 species each. The most frequently used part was the leaf and the most common method of preparation and administration was decoction that was taken orally. One of the most culturally important medicinal plants was Euphorbia hirta L. with the highest use value (0.59) for treating visual problems, dengue, typhoid fever, and headache. The result of this study serves as an ethnobotanical base for drug research and formulation, as well as creating the needed awareness for preserving ethnomedicine as a safe and effective alternative means in the health care delivery system.
\end{abstract}

Keywords: Antique, Ati, indigenous knowledge, medicinal plants, Philippines

\section{INTRODUCTION}

The Philippines is one of the 17 megadiverse countries that harbor more than $75 \%$ of world's flora and fauna (CBD 2019). The country ranks eighth on the world's list of endemic plants and reptiles and fifth in birds and mammals (Ong et al. 2002). In terms of cultural diversity, it has more than 14 million indigenous peoples in 110 groups occupying approximately $45 \%$ of the national land territory (NEDA 2017).

In Western Visayas, one of the major groups of indigenous peoples being recognized by the National Commission on Indigenous Peoples (NCIP) is the Negritos, locally known as "Ati". The Ati are the aborigines of the Philippines comprising about 25-34 tribal groups living in the major islands of the country and known in various names (Headland 1987; Padilla 2013). They have short stature, dark skin, curly hair, flattened nose, and their bodies are covered with thick hairs. They can be found in Northeast Mindanao, Samar, Central Negros, Central Panay, a few small islands north of Panay, North-Central Palawan, few isolated points in Southern Luzon, mountains of Bataan, and Zambales (Worcester 1913). In Panay Island, most of them wander by bands in the mountainous areas of the region and engaged in gradual clearing of the forest. Subsequently, they adopted a semi-sedentary life and work as farm laborers in the lowlands (Beyer 1917). They speak Inati, Kiniray-a, and Hiligaynon dialects, and some can speak and understand Filipino and English.
Unfortunately, Inati is a threatened language and there are only few thousand people who used it (Eberhard et al. 2020).

One of the most disadvantaged, marginalized, and poorest communities in the country are the indigenous peoples (IPs), who are mostly living in remote areas around the archipelago (UNDP 2010). Due to their isolated location, poverty, and lack or absence of access to basic health services, most of them rely on herbal medicines to address their primary health care needs instead of seeking assistance from licensed medical practitioners (PCHRD 2013). The Ati in Panay is known as gatherers, peddlers, traders, and sellers of medicinal plants to the communities in the towns, cities, and nearby islands (de la Peña 2009; Zayas 2008). Though they are known as the source of medicinal plant products, limited studies have been published about the medicinal plants they used in traditional medicine. Some medicinal plants were mentioned in the anthropological studies conducted in the Ati community in Janiuay, Iloilo (Rahmann and Maceda 1958), and in some barangays in Hamtic, Tibiao, and Dao, Antique (Rahmann and Maceda 1962). An ethnopharmacological study on 46 plants was conducted in the Ati resettlement in Barotac Viejo, Iloilo (Madulid et al. 1989), and recently a comprehensive listing in Malay, Aklan (Cordero et al. 2020). There is no updated and detailed documentation focused on the medicinal plants used by the Ati in the province of Antique.

Antique is a seahorse-shaped province straddled in the 
western coastal part of the Panay Island in Western Visayas. It is bounded by the province of Capiz in the North, Cuyo East Pass in the west, Panay Gulf in the south, and a rugged of 35 mountain chains in the west that borders the province from Iloilo and Aklan (Fornier 1998). The province derived its name from "hantic-hantic" referring to a large species of ant ubiquitous in the province. It is also known as the "Home of the Sacadas" due to most of the laborers work in sugarcane plantations in Negros Occidental. It has a total land area of 252,201 hectares (ha), $53 \%(133,566$ ha) classified as A \& D while $47 \%(118,635$ ha) classified as forestland, and it has the highest forest at $28 \%(72,022.25 \mathrm{ha})$ among the six provinces in Panay Island (DENR 2019). The province is home to more than 9,000 Ati scattered in six municipalities (NCIP 2019).

The rapid land degradation, accelerated forest destructions, loss of biological diversity, access to modern medicine, exposure to modern culture, mobility, and displacement of communities may affect the traditional knowledge of the indigenous peoples as well as the variety of the medicinal plants present in their area. Traditional practices used by the IPs were handed to the next generation normally in oral forms. The continuing loss of traditional knowledge is due to the absence of verbal communication to the next generation (Longuefosse and Nossin 1996). It is therefore urgent to document these data before it is totally forgotten. The present study aims to document the ethnobotanical knowledge on the medicinal plants used by the indigenous Ati tribe in Sitio Pantad, Brgy. Igcalawagan, Tobias Fornier, Antique.

\section{MATERIALS AND METHODS}

\section{Study area}

The study was conducted in Sitio Pantad, Brgy. Igcalawagan, Tobias Fornier (formerly Dao) Antique (Figure 1). The Ati community is situated in a property donated by a priest as a settlement for wandering and landless Ati families. The community was officially recommended by the Chief Division Officer of the NCIP Aklan/Antique Community Service Center (ACSC). The tribe has preserved cultural integrity and still practices their indigenous customs and traditions. Certification Precondition was issued by the NCIP-Region VI/VII and the researchers satisfactorily complied with the requirements by the NCIP Administration Order 1, Series of 2012 also known as "The Indigenous Knowledge Systems and Practices (IKSPs) and Customary Laws (CLs) Research Documentation Guidelines of 2012". Wildlife gratuitous permit was also acquired from the Department of Environment and Natural Resources (DENR) Region VI prior to the conduct of the study.

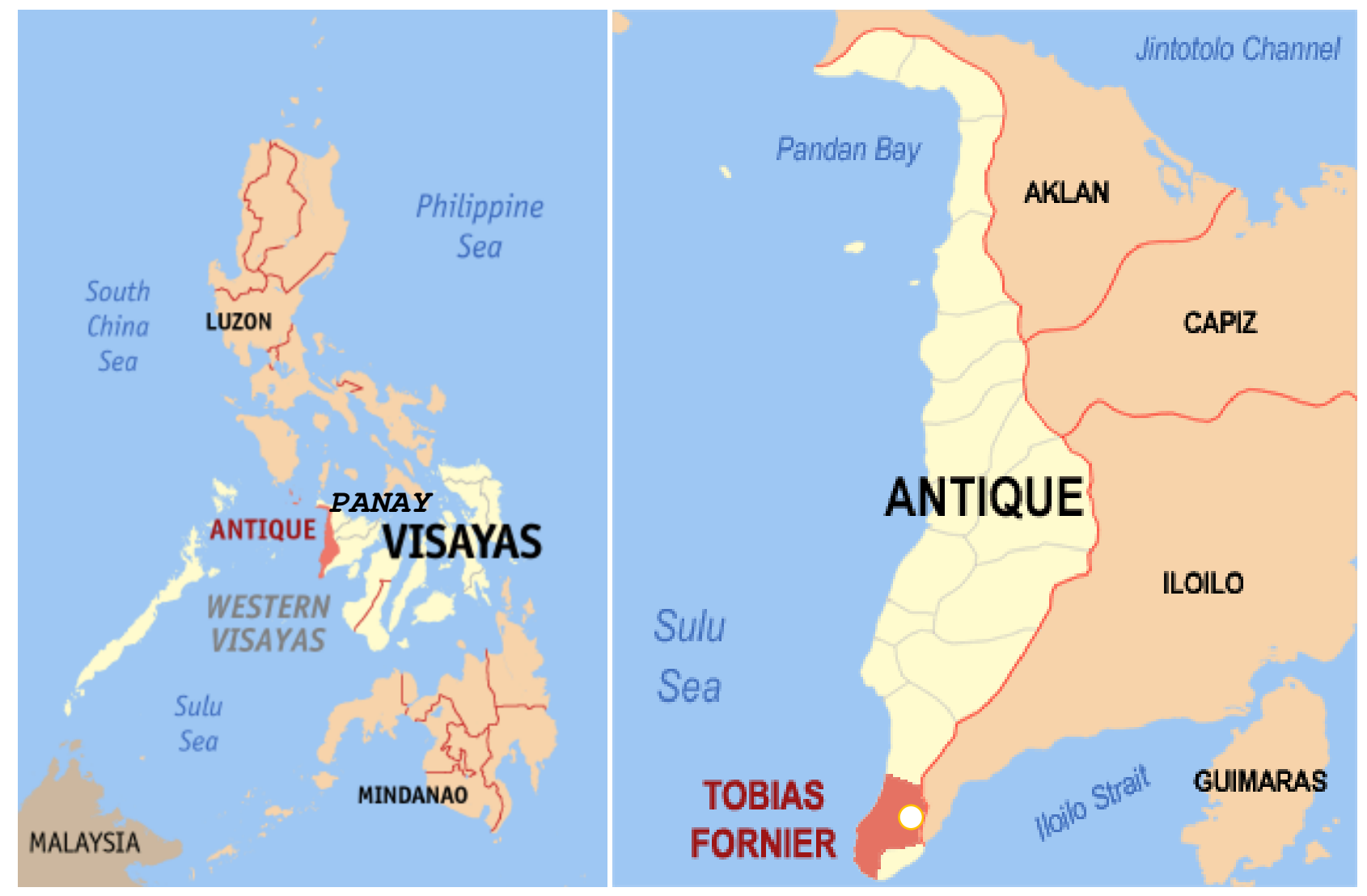

Figure 1. Location of the study site shaded in red: A. Panay Island in Visayas region of the Philippine archipelago, B. Municipality of Tobias Fornier in the Province of Antique, Panay Island, indicated Brgy. Igcalawagan (white dot) 


\section{Data collection}

A semi-structured questionnaire, ethically reviewed and approved by the (Ethics Review Committee of the University of Santo Tomas-Graduate School (GS-2017-PN 146) was used to interview the informants. The documentation of the medicinal plants was conducted using a purposive sampling and the key informants were determined during one of the community consultative meetings with the NCIP officers and legal counsel. The informants were composed of the tribal chieftain, council of elders, herb doctors, and other members of the tribe who have indigenous knowledge of using medicinal plants in treating and addressing health problems and conditions. There were 22 informants $(>10 \%$ of the Ati population in Sitio Pantad). They were interviewed at their own convenience in their community in February and April 2019. They were asked for their personal information and the medicinal plants they used when they experienced any health-related problems or conditions. Plant part used, mode of preparation, and administration were also recorded during the interviews. A focus group discussion was also conducted for the verification of the acquired data among the informants.

\section{Plant collection and identification}

Collection of medicinal plant samples were carried out with the help of the informants, herb doctors, and other members of the tribe that was knowledgeable on the identification and location of the medicinal plants. Medicinal plants were photographed for documentation purposes. The voucher specimens were prepared using five branches with preferably reproductive parts (flowers and fruits), poisoned, pressed, and dried. The pressed and dried medicinal plants were mounted on herbarium sheets with proper documentation labels. The herbarium specimens were deposited in the Herbarium of the Northwestern University Luzon (HNUL) and in the University of Santo Tomas Herbarium (USTH). Identification of the collected medicinal plants was done using different online databases such as Co's Digital Flora of the Philippines and PhytoImages (Pelser et al. 2011), Stuartxchange (http://www.stuartxchange.org), and Plants of the World Online (POWO 2019), then verified by Mr. Danilo Tandang, a botanist at the Philippine National Museum Herbarium. For the validation of the family and scientific names, The Plant List (The Plant List 2013), Tropicos (2019), and World Flora Online (WFO 2019) were used.

\section{Data analyses}

There were three values calculated to quantify the importance of medicinal plants: use value (UV), informant consensus factor (ICF), and fidelity level (FL). The UV was used to assess the relative importance of the medicinal plants using the formula: $\mathrm{UV}=\mathrm{U} / \mathrm{N}$, where $\mathrm{U}$ is the number of users report cited by each informant for a particular species, and $\mathrm{N}$ is the total number of informant (Phillips and Gentry 1994). When an informant cited a medicinal plant as being used for any healthcare purpose or disease, it is considered as one use-report. Plants with one use report were not computed for the UV. On the other hand, ICF was used to determine the culturally important and potentially effective medicinal plant species using the formula: $\mathrm{ICF}=\left(\mathrm{N}_{\mathrm{ur}}-\mathrm{N}_{\mathrm{t}}\right) /\left(\mathrm{N}_{\mathrm{ur}}-1\right)$, where $\mathrm{N}_{\mathrm{ur}}$ is the number of useful reports in each disease category, and $\mathrm{N}_{\mathrm{t}}$ is the number of species used (Heinrich et al. 1998). The result ranges from 0 to 1 , and the value closest to 1 indicates that few medicinal plant species were being used by the informants in the same category, while a value close to 0 indicates that there were many medicinal plant species used to treat a disease or illness in the same category. The disease categories were adapted from the International Classification of Diseases (ICD-11 Mortality and Morbidity Statistics) by the World Health Organization (WHO 2020). Lastly, FL was used to evaluate the percentage of the most preferred medicinal plant species for a particular category using the formula: $\mathrm{FL}=\left(\mathrm{N}_{\mathrm{p}} / \mathrm{N}\right) \times 100$. Where, $\mathrm{N}_{\mathrm{p}}$ is the number of informants who cited the use of a particular medicinal plant species for the same category of disease, and $\mathrm{N}$ is the total number of informants who cited the plant species for any other use or purpose (Friedman et al. 1986). A high value indicates that a medicinal plant was considered the most preferred species by the informants for a particular category, and low value indicates that many species were used in the same category.

\section{RESULTS AND DISCUSSION}

\section{Medicinal plant habit and characteristics}

A total of 108 medicinal plant species distributed in 97 genera and 44 families were used by the Ati tribe to address 67 diseases or purposes in 12 different categories. The family Fabaceae (Leguminosae) was best represented with 15 medicinal plant species, followed by Lamiaceae with 12 species, and Asteraceae, Euphorbiaceae, and Poaceae with 5 species each (Figure 2). The detailed list of the documented medicinal plants used by the Ati tribe was summarized in Table 1 . The scientific names, family, and local names of the plants were included along with the part used, disease or purpose, mode of preparation, and form of administration.

The medicinal plants documented and collected were diverse and composed of herbs (39\%), trees (32\%), shrubs (22\%), and climbers (7\%) (Figure 3). Most of the medicinal plants were collected in the wild. The plants were found growing along the trail in the mountains, along the dry riverbed, and as weeds in the rice fields. The cultivated ones were grown as ornamentals, crops, vegetables, and for medicinal purposes by the Ati in their community.

\section{Plant part used and mode of preparation and administration}

Fifteen different medicinal plant parts were used by the Ati tribe to address their health conditions and problems. The most frequently used parts were the leaf $(40 \%)$, followed by root (17\%), stem (12\%), and bark (8\%). Fruit, latex, seed, rhizome, flower, whole plant, tuber, petiole, bulb, adventitious roots, and shoots were also used but less 
frequently (Figure 4). Leaves were applied as fresh, heated, crushed, pounded, and boiled depending on the disease or illness to be addressed. Sometimes sugar or mother's breastmilk was mixed with the leaf extract to be taken by the infants and children to mask or reduce the taste of bitterness. In some instances, salt was added to the poultice before treatment. Roots were usually boiled and the decoction was taken orally. Sometimes it is infused in coconut (Cocos nucifera L.) oil and applied topically or dried and placed in a small pouch to serve as an amulet (karmen-karmen) for infants and babies. Stems were usually boiled, infused in coconut oil, soaked in warm water, and its extract was consumed orally. Fruits were normally eaten as fresh, processed into oil or vinegar, boiled, heated, and applied directly.

The most common methods of preparation and administration were drinking decoction (28\%), applying plant part/s directly on the affected area (17\%), and crushing or pounding and applying or rubbing extract $(16 \%)$, bathing or washing decoction $(8 \%)$, and soaking in water to drink (7\%) (Figure 5). Applying the latex onto the affected area or instillation into the eyes; burning plant parts for incense and ash; eating, chewing, and drinking water or juice from fruits; infusing in oil, vinegar, and gin; and processing into oil or vinegar were also practiced. Plants were also used as an amulet, bracelet, necklace, and a warning sign (plant part hung at the window).

Decoction was done by boiling seven fresh leaves or other plant parts such as fruits, roots, and barks in three glasses of water for five minutes, cooled down, and taken orally. It was usually prepared from a single medicinal plant or in mixture (polyherbal) with other plants (usually 3 , 5, or 7 different plant species). For bathing, decoction was done by boiling the mixture of medicinal plants in a large pot half-filled with water for five minutes and cooled down by adding tap water. The Ati tribe was accustomed to use pito-pito (pito means seven) different medicinal plants or plant parts for the preparation of the remedy. For example, in the postpartum care recovery, seven different medicinal plants were boiled for the preparation of the treatment, and for measles or chickenpox, seven seeds of Vigna radiata (L.) R. Wilczek was used (Table 1). Sometimes three or five (odd numbers) different plants or plant parts were also used in treating diseases or illness.

\section{Use value}

The use-value was used to determine the relative importance of the medicinal plants as indicated with high use reports. Medicinal plants with highest UV were Euphorbia hirta L. (0.59), followed by Jatropha curcas L. (0.55), and Spondias purpurea L., Tabernaemontana pandacaqui Lam., and Chrysophyllum cainito L. and Hyptis suaveolens (L.) Poit. with 0.50 value each. E. hirta was used in three categories and was frequently used for treating visual problems, typhoid fever, dengue, and headache. For eye problems such as sore eyes, conjunctivitis, cataract, and blurry vision, latex from the stem was dropped into the affected eye/s. For dengue, typhoid fever, and headache it was prepared by boiling alone or with Mimosa pudica L., and the decoction was taken orally or applied as sponge bath. E. hirta grows as weeds everywhere in the community and readily available when needed. J. curcas was used in four categories and known to suppress headache, nausea, oral thrush, tooth decay, and fracture. Leaves were applied on the forehead, or forehead and stomach area for headache and nausea. For fracture, fresh leaves or fresh or heated barks were applied to the affected area. Latex from the petiole was dropped into the tongue for oral thrush, and for tooth decay, the latex was applied in cotton and inserted into the affected tooth. S. purpurea was used in one category for the treatment of oral thrush in infants and children. The inner bark was scraped, and the extract was dropped into the tongue. T. pandacaqui was used in one category for the treatment of skin problems such as boil, pus, and other skin diseases. Latex from the stem was applied directly on the affected area. C. cainito was used in four categories and commonly known to treat cough, diarrhea, stomachache, pulmonary problems, and anthelmintic. Leaves, stem, roots, or barks were boiled alone or with Syzygium cumini (L.) Skeels and Pithecellobium dulce (Roxb.) Benth., and the decoction was taken orally. Leaves were also applied to the back of the body for pulmonary problems. $H$. suaveolens was used in two categories for the treatment of diarrhea, stomachache, bloated stomach, and athlete's foot. Heated leaves were crushed and applied on the stomach for stomachache bloated stomach, and diarrhea. In some case, pounded leaves were wrapped in banana leaf with seven rice grains then heated over the flame and applied on the stomach. Sometimes roots were boiled and the decoction was taken orally. For athlete's foot, leaves were crushed and the extract was rubbed on the affected area. Medicinal plants with the highest use value were frequently used by the Ati tribe in traditional medicine and can be found growing near their community and were available when they needed it.

\section{Informant consensus factor}

A total of 67 diseases or purposes in 12 categories were documented in this study (Table 2). The ICF value was based on the number of use reports and the number of medicinal plant species used in each category. The results range from 0.43 to 1.00 and the highest value was in category 6: mental, behavioral, or neurodevelopmental disorders. The reported disease was mental disorder and the frequently used plant was Donax canniformis (G.Forst.) K.Schum. by applying leaves on the forehead or bathing leaves decoction. Though the ICF value was high in category 6 (1.00), only few informants cited the use of $D$. canniformis. The second highest value (0.77) was in category 1: certain infectious or parasitic diseases and the documented disease or purpose were anti-rabies, antitetanus, anthelmintic, athlete's foot, chickenpox, dengue, typhus, typhoid fever, measles, oral thrush, ringworm, snake bite, and tinea versicolor treatment. S. purpurea was frequently used plant and was widely used to cure oral thrush. The third highest value (0.74) was in category 9: diseases of the visual system and E. hirta was frequently used medicinal plant species for treating visual problems. The lowest ICF value was in category 11: Diseases of the circulatory system with edema as a reported disease and Crinum sp. L. was the frequently used species. 
Table 1. Medicinal plants used by the indigenous Ati tribe in Sitio Pantad, Brgy. Igcalawagan, Tobias Fornier, Antique, Philippines

\begin{tabular}{|c|c|c|c|c|c|c|c|}
\hline Scientific name & $\begin{array}{l}\text { Accession } \\
\text { number }\end{array}$ & Family name & Local name & $\begin{array}{c}\text { Use } \\
\text { value }^{\mathrm{a}}\end{array}$ & $\begin{array}{r}\text { Plant } \\
\text { part } \\
\text { used }^{b}\end{array}$ & Disease or purpose & Preparation and administration \\
\hline Justicia gendarussa Burm.f. & HNUL0020567 & Acanthaceae & Bunlaw & 0.09 & Lf & $\begin{array}{l}\text { Postpartum care and } \\
\text { recovery }\end{array}$ & $\begin{array}{l}\text { Boil with Glochidion sp., Bambusa sp. or with Canarium sp., } \\
\text { P. pentandrum, and } C \text {. citratus then drink } 1 \text { glass of } \\
\text { decoction and bath the rest }\end{array}$ \\
\hline \multirow{2}{*}{$\begin{array}{l}\text { Pseuderanthemum carruthersii } \\
\text { (Seem.) Guillaumin }\end{array}$} & HNUL0020596 & Acanthaceae & Pasaw & 0.23 & Lf & Headache & Apply on the forehead; Boil and bath decoction \\
\hline & & & & & $\mathrm{Lf}$ & $\begin{array}{l}\text { Postpartum care and } \\
\text { recovery }\end{array}$ & Boil and bath decoction \\
\hline \multirow[t]{2}{*}{ Acorus calamus $\mathrm{L}$. } & HNUL0020599 & Acoraceae & Labigan & 0.14 & $\mathrm{Rh}$ & Headache, hiwit (sorcery) & Drink decoction \\
\hline & & & & & $\mathrm{Rh}$ & $\begin{array}{l}\text { Karmen-karmen } \\
\text { (amulet) }\end{array}$ & $\begin{array}{l}\text { Slice dried roots with Uncaria sp., M. pruriens, } L \text {. } \\
\text { guineensis, \& Alocasia cv., put in a small pouch and pin in } \\
\text { child's clothes }\end{array}$ \\
\hline \multirow[t]{2}{*}{ Crinum sp. L. } & HNUL0020595 & Amaryllidaceae & Bakong/ bakom & 0.14 & $\mathrm{Bu}$ & Boil & Grate and apply \\
\hline & & & & & $\mathrm{Bu}$ & Edema & Heat sliced bulb and apply \\
\hline Spondias purpurea $\mathrm{L}$. & HNUL0020571 & Anacardiaceae & Sergwelas & 0.5 & $\mathrm{Bk}$ & Oral thrush & Scrape inner bark and drop extract on the child's tongue \\
\hline \multirow{4}{*}{ Annona muricata $\mathrm{L}$. } & HNUL0020580 & Annonaceae & Babana & 0.32 & $\mathrm{Lf}$ & Cuts, wounds & Apply crushed leaves \\
\hline & & & & & Lf, Fr & $\begin{array}{l}\text { Stomach ulcer, intestinal } \\
\text { cleansing }\end{array}$ & Drink decoction of young fruit or leaves \\
\hline & & & & & $\mathrm{Bk}$ & $\begin{array}{l}\text { Urinary tract infection } \\
\text { (UTI) }\end{array}$ & $\begin{array}{l}\text { Boil alone or with } H \text {. riparia, I. cylindrica, E. philippinensis, } \\
\text { and } L . \text { speciosa and drink decoction }\end{array}$ \\
\hline & & & & & $\mathrm{Lf}$ & Cough, cancer & Drink decoction \\
\hline \multirow[t]{2}{*}{ Alstonia scholaris (L.) R.Br. } & HNUL0020546 & Apocynaceae & Bita & 0.45 & $\mathrm{Bk}$ & $\begin{array}{l}\text { Stomachache, UTI, } \\
\text { abortifacient }\end{array}$ & $\begin{array}{l}\text { Drink decoction; pound dried bark then add in warm water } \\
\text { and drink }\end{array}$ \\
\hline & & & & & $\mathrm{Bk}$ & Dizziness, gas pain & Soak in water and drink \\
\hline Catharanthus roseus (L.) G.Don & HNUL0020606 & Apocynaceae & $\begin{array}{l}\text { Pandanggera/ } \\
\text { Rosas de } \\
\text { baybayon }\end{array}$ & & Rt & Abortifacient & Drink decoction \\
\hline \multirow[t]{2}{*}{$\begin{array}{l}\text { Parameria laevigata (Juss.) } \\
\text { Moldenke }\end{array}$} & HNUL0020548 & Apocynaceae & Tagulaway & 0.41 & $\begin{array}{l}\text { Rt, St, } \\
\text { Lx }\end{array}$ & $\begin{array}{l}\text { Cuts/wounds, skin } \\
\text { disease }\end{array}$ & $\begin{array}{l}\text { Infuse slice dried root alone or with } C \text {. cinereum in } C \text {. } \\
\text { nucifera's oil then apply; Burn stem and apply the ash; Apply } \\
\text { latex directly }\end{array}$ \\
\hline & & & & & Rt & Vomiting blood & Boil with Ardisia sp. and drink decoction \\
\hline $\begin{array}{l}\text { Tabernaemontana pandacaqui } \\
\text { Lam. }\end{array}$ & HNUL0020543 & Apocynaceae & Alibotbot & 0.5 & $\mathrm{Lx}$ & Pus, boil, skin diseases & Apply latex to the affected area \\
\hline \multirow[t]{2}{*}{ Alocasia cultivar (Schott) G.Don } & HNUL0020601 & Araceae & Badyang tapol & 0.14 & $\mathrm{Lf}$ & Inaswang (witchcraft) & Apply on the abdomen \\
\hline & & & & & $\mathrm{Tu}$ & $\begin{array}{l}\text { Karmen-karmen } \\
\text { (amulet) }\end{array}$ & $\begin{array}{l}\text { Slice dried tuber with Uncaria sp., A. calamus, L. guineensis, } \\
\& \text { M. Pruriens, put in a small pouch and pin in child's clothes }\end{array}$ \\
\hline Alocasia macrorrhizos (L.) G.Don & HNUL0020594 & Araceae & Badyang & 0.23 & $\mathrm{Pt}$ & Toothache & $\begin{array}{l}\text { Burn the decaying petiole with husk of } C \text {. nucifer } a \text { then wrap } \\
\text { ash in a black cloth and rub on the face }\end{array}$ \\
\hline
\end{tabular}




\section{Areca catechu $\mathrm{L}$.}

Cocos nucifera $\mathrm{L}$

HNUL0020604 Arecaceae

HNUL0020609 Arecaceae

Sansevieria trifasciata Prain

HNUL0020597 Asparagaceae

Artemisia vulgaris $\mathrm{L}$.

Blumea balsamifera (L.) DC.

Blumea lacera (Burm.f.) DC.

Chromolaena odorata (L.)

R.M.King \& H.Rob.

Cyanthillium cinereum (L.) H.Rob HNUL0020577 Asteraceae

Cordia dichotoma G.Forst.

HNUL0020575

HNUL0020540 Boraginaceae

Heliotropium indicum $\mathrm{L}$.

Ananas comosus (L.) Merr.

HNUL0020598 Bromeliacea

HNUL0020542 Burseraceae Salong

Canarium sp. L.

HNUL0020557 Caricaceae

Carica papaya $\mathrm{L}$

Cheilocostus speciosus (J.Koenig) HNUL0020551 Costaceae C.D.Specht
Bunga

Niyog

Kapayas

0.14 Sd Stomachache, bloated

stomach

$0.23 \mathrm{Fl} \quad$ Edema

Fr Urinary tract infection

Fr Cuts, wounds, cough,

spasm

Tigre-tigre

0.23 Fr

Cuts, Wounds; anti-

tetanus

0.27 Lf Cough

\section{Lf Gas pain}

0.27 Lf, Rt Cough

0.32 Lf, Rt Stomachache, gas pain

Dila-dila

Bungarngar/ Melda-melda

Pali-pali

Anonang

Kamra-kamra

Pinya

Tabungyan

\section{Lf Cuts, wound \\ 0.18 Lf Cuts, wounds \\ Lf Stomachache}

$0.27 \mathrm{Rt} \quad$ Cuts/wounds

0.18 Lf, Rt Promote placenta and

fetus development

$0.09 \mathrm{Rt}$ Diarrhea

Lf Cuts, wounds

0.32 Lf Fever

$\begin{array}{rll} & \text { Lf } & \text { Hair loss } \\ & \text { Lf } & \text { Typhus } \\ 0.32 & \text { Lx } & \text { Postpartum care and } \\ & & \text { recovery }\end{array}$

recovery

$0.32 \mathrm{Fr} \quad$ UTI, constipation

Fr Anti-rabies

Sd Stomachache

Lf Dengue, fever

$0.14 \mathrm{Rh} \quad$ Dizziness

St Relapse
Chew or pound with $P$. betle and $N$. tabacum then apply on the stomach

Process into vinegar then add $T$. crispa and apply

Drink water from the fruit

Process into oil then add E. indica, Alpinia sp., P. laevigata, \& A. flava and apply

Process into oil then add $F$. benjamina and apply on the scalp

Crush heated leaves and apply

Drink extract alone or with breastmilk for infants; rub extract on the throat or on the chest and back of the body

Rub extract on the stomach

Eat young leaves; crushed leaves and rub extract on the throat; drink root or leaf decoction

Apply leaves as poultice alone or with Z. officinale on the stomach; drink root decoction; wrap pounded leaves with bit of salt in banana's leaf then heat and apply on the stomach

Apply crushed leaves

Apply crushed leaves

Wrap pounded leaves in banana's leaf then heat and apply on the stomach

Infused with P. laevigata in C. nucifera's oil and apply

Apply leaves on the abdomen; Drink root decoction

Drink decoction

Apply crushed leaves

Pound and rub extract on the body; soaked in water for sponge bath

Pound and rub extract on the head

Pound and rub extract

Boil latex with Glochidion sp. or bark with P. pendandrum,

C. maxima \& C. citratus then drink 1 glass and bath the rest

Burn and mix ash with water and drink or wrap latex in

banana leaf

Eat ripe fruit

Rub latex

Pound 7 dried seeds then soak in warm water and drink

Boil then drink some decoction and sponge bath the rest

Drink decoction

Cut in half vertically then heat over the flame and apply on the forehead 
HNUL0020538 Euphorbiaceae Miyagos

Jatropha curcas L.

HNUL0020593 Euphorbiaceae Kasla

Melanolepis multiglandulosa

(Reinw. ex Blume) Rchb. \& Zoll.

Ricinus communis $\mathrm{L}$.

Adenanthera pavonina $\mathrm{L}$.

Archidendron clypearia (Jack)

I.C.Nielsen

Caesalpinia sappan $\mathrm{L}$

Caesalpinia sp. L.

Desmodium sp. Desv.

Desmodium triflorum (L.) DC.

Gliricidia sepium (Jacq.) Walp.

HNUL0020561 Euphorbiaceae Alom

Euphorbiaceae Tangan-tangan

HNUL0020586 Fabaceae

HNUL0020525 Fabaceae

HNUL0020582 Fabaceae

HNUL0020520 Fabaceae

HNUL0020531 Fabaceae

HNUL0020530 Fabaceae

HNUL0020579 Fabaceae

Indigofera tinctoria $\mathrm{L}$.

HNUL0020573 Fabaceae

Tagum

Mimosa pudica L.

HNUL0020547 Fabaceae

Huya-huya

Pipi

Sibukaw

Sapinit

Ikog-ikog

Himbis puyo

Madre Kakaw

HNUL0020590 Fabaceae

Nipay
0.45 Lf

Lf

$0.23 \mathrm{Lf}$

Rt

$0.59 \mathrm{Lx}$

Wp Denoue, typhoid fever

headache

0.36 Rt Stomach ulcer,

appendicitis, intestinal

cleansing

Rt UTI, kidney stones

$\begin{array}{lll}0.55 & \text { Lf } & \text { Headache } \\ \text { Lf } & \text { Nausea } \\ \text { Lf, Bk } & \text { Fracture } \\ \text { Lx } & \text { Thrush, tooth decay }\end{array}$

0.27 Lf Dizziness, headache

$\begin{array}{lll} & \text { Lf } & \text { Sore eyes } \\ 0.09 & \text { Lf } & \text { Migraine }\end{array}$

0.14 Lf Cough

$0.14 \mathrm{Bk} \quad$ Dandruff

St Soap

Vomiting blood

Sore eyes

Lf Stomachache

0.32 Rt, St, Thrush

$\begin{array}{ll}\text { Lf } & \\ \mathrm{Wp} & \text { Fever }\end{array}$

$\begin{array}{lll}0.18 \mathrm{Wp} & \text { Fever } \\ 0.32 \mathrm{Lf} & \text { Headache }\end{array}$

Lf Postpartum bleeding

Lf, St Skin disease

0.27 Lf Stomachache; Bloated stomach

$\begin{array}{rll}0.23 & \mathrm{Wp} & \text { Dengue } \\ & \mathrm{Rt} & \text { Stones } \\ & \mathrm{Rt} & \text { Vomiting blood } \\ 0.23 & \mathrm{St} & \text { Thrush } \\ & \mathrm{Rt} & \text { Karmen-karmen } \\ & & \text { (amulet) }\end{array}$

Drink extract

Crush heated leaves and damp extract on the infant's mouth

Apply crushed leaves

Boil alone or with E. indica \& D. triflorum and drink

decoction
, Drop latex into the eyes

Boil alone or with M. pudica drink decoction or apply as sponge bath

Boil alone or with I. cylindrica and drink decoction

Boil alone or with M. pudica, I. cylindrica or E. philippinensis, L. speciosa, \& A. muricata and drink decoction Apply on the forehead or forehead and stomach Apply on the stomach area

Apply leaves; Apply fresh or heated bark

Drop into the tongue; apply latex in cotton and insert in the affected tooth

Apply on the forehead

Drop extract into the eyes

Apply on the forehead

Pound then add sugar in extract and drink

Scrape bark and rub extract on the scalp

Pound dried stem and use as soap

Drink decoction; soak in water and drink

Drop extract into the eyes

Drink decoction

Use roots or stem as bracelet or necklace for infants and

children; Rub leaf extract on the tongue

Boil alone or with $E$. indica \& $K$. odorata and drink

decoction

Apply on the forehead

Heat over the flame and seat on it

Crush and apply leaf extract; scrape stem and apply extract

Crush leaves alone or with $P$. angulata \& L. esculentum and rub extract on the stomach; Wrap pounded leaves in banana's leaf then heat and apply on stomach

Boil with E. hirta and drink decoction

Boil with $I$. cylindrica \& $H$. riparia and drink decoction

Boil with $E$. indica and drink decotion

Apply extract

Slice dried roots with Uncaria sp., A. calamus, L. guineensis, \& Alocasia $\mathrm{cv}$., put in a small pouch and pin in child's clothes 
Pithecellobium dulce (Roxb.)

Benth.

Pterocarpus indicus Willd.

Senna alata (L.) Roxb.

Tamarindus indica $\mathrm{L}$.

Vigna radiata (L.) R.Wilczek

Cratoxylum sumatranum (Jack)

Blume

Clerodendrum quadriloculare

(Blanco) Merr.

Hyptis capitata Jacq.

Hyptis suaveolens (L.) Poit.

Gmelina arborea Roxb.

Gmelina elliptica $\mathrm{Sm}$.

Leucas zeylanica (L.) W.T.Aiton Ocimum sp. L.

Plectranthus amboinicus (Lour.) Spreng.

Plectranthus scutellarioides (L.)

R. $\mathrm{Br}$

\section{Premna odorata Blanco}

Vitex negundo $\mathrm{L}$

Vitex trifolia L.

Lagerstroemia speciosa (L.) Pers. HNUL0020518 Lythraceae
HNUL0020524 Lamiaceae

HNUL0020570 Lamiaceae

HNUL0020541 Lamiaceae

Kamunsil

Naga

Palotsina

Salamagi

Monggo

HNUL0020600 Fabacea

HNUL0020529 Hypericacea

Kansilay

HNUL0020554 Lamiaceae

Salin-uwak

Bulang-

bulang/Gulang-

gulang

HNUL0020532 Lamiaceae Luko-luko

HNUL0020558 Lamiaceae

HNUL0020553 Lamiaceae

HNUL0020572 Lamiaceae

HNUL0020568 Lamiaceae

HNUL0020619 Lamiaceae

HNUL0020620 Lamiaceae

(kamang)

Banaba

Gimelina

Talungon

Pitsi-pitsi

Kulukulugo

Oregano

Rapunaya

Lumabong

Lagundi (kahoy)

0.27
0.
0.09
0.
0.

\section{St Diarrhea}

27 Toothache

Tinea versicolor,

ringworm

0.14 Lf Cough

0.09 Sd Measles, Chickenpox

0.13 Rt, Lf Postpartum care and

0.18 Lf Headach

Lf Bloated stomach,

constipation

Rt Constipation

0.5 Lf, Rt Stomachache, diarrhea,

\section{bloated stomach}

Lf Athlete's foot

Headache

$0.18 \mathrm{Fr}$

Boil

$0.14 \mathrm{Rt} \quad$ Skin abscess

$\begin{array}{lll}0.14 & \text { Rt } & \text { Stomachache } \\ 0.18 & \text { Lf } & \text { Cough }\end{array}$

Cough

0.27 Lf Cough

0.32 Lf

Cough

Lf Fever

0.18 Lf Black eye

Lf Headache

St, Rt Dizzines

0.45 Lf, St Cough

0.14 Lf, St Spasm

\section{Lf Cough}

$0.36 \mathrm{Bk}, \mathrm{Lf} \quad \mathrm{UTI}$, stomach ulcer, appendicitis; uterine problems; gallbladder problems, vomiting blood

Lf Headache
Boil with S. cumini \& C. cainito and drink decoction

Drop into the affected tooth

Pound and rub extract

\section{Drink extract}

Soak 7 seeds in water alone or with A. bunius and drink

Drink root decoction; apply leaves on the forehead

Apply on the forehead

Apply leaves as poultice on the stomach

Drink root decoction

Crush heated leaves and apply on the stomach; wrap pounded

leaves in banana leaf with 7 rice grains heat over the flame

and apply on the stomach; drink root decoction

Crush and apply

Apply on the forehead

Cut in half then heat and apply

Heat and apply

Drink decoction

Crush heated leaves and add salt then apply

Crush and rub extract on the stomach

Crush heated leaves and rub extract on the back; crush in

water and drink; crush and drink extract

Crush and drink extract or rub extract on the throat and on the back of the body

Crush and rub extract on the forehead

Crush and apply extract

Apply on the forehead

Drink decoction

Drink leaf decoction; soak stem in warm water and drink

Drink leaf decoction; infused stem in $C$. nucifera oil with $Z$ officinale \& $C$. citratus and rub; infused stem with $N$.

tabacum in C. nucifera's oil and rub

Crush and rub extract

Boil alone or with $H$. riparia, I. cylindrica, E. philippinensis

\& L. speciosa and drink decoction

Apply on the forehead 
Duldol

Theobroma cacao $\mathrm{L}$.

Donax canniformis (G.Forst.)

K.Schum.

Arcangelisia flava (L.) Merr.

Kakaw

Banban

(1)

HNUL0020603 Menispermaceae Albutra
Swietenia mahogoni L.
HNUL0020585 Meliaceae Mahogany

Tinospora crispa (L.) Hook. f. \& HNUL0020565 Menispermaceae Manunggal Thomson

HNUL0020581 Moraceae Lunok

\section{Ficus nota (Blanco) Merr.}

Ficus pseudopalma Blanco

Ficus septica Burm.f.

Moringa oleifera Lam.

Musa $\mathrm{x}$ paradisiaca $\mathrm{L}$

Psidium guajava $\mathrm{L}$

Syzygium cumini (L.) Skeels

HNUL0020569 Myrtaceae

HNUL0020617 Piperaceae

$\begin{array}{lll}\text { HNUL0020592 } & \text { Moraceae } & \text { Tabuyog } \\ \text { HNUL0020555 } & \text { Moraceae } & \text { Salamnyog } \\ \text { HNUL0020544 } & \text { Moraceae } & \text { Lamnog }\end{array}$

HNUL0020544 Moraceae Lamnog

HNUL0020613 Moringaceae

Balunggay

HNUL0020614 Musaceae HNUL0020563 Myrtaceae

Bayabas

Lumboy

Piper betle L.
Ficus benjamina L.

$\begin{array}{rll}0.27 & \text { Bk } & \text { Stomachache } \\ & \text { Lf } & \text { Headache } \\ 0.23 & \text { Fr } & \text { Burn } \\ 0.18 & \text { Lf } & \text { Mental disorder } \\ & & \\ & \text { Rt } & \text { Measles } \\ 0.27 & \text { Sd } & \text { Tooth decay } \\ & \text { Sd } & \text { Stomachache, diarrhea } \\ & \text { Sd } & \text { Abortifacient } \\ 0.23 & \text { St, Rt } & \text { Gas pain }\end{array}$

Saging tundal
Buyo
Lf Diarrhea
0.23 St, Rt Gas pain

St Postpartum care and

recovery, stomachache

St Sore eyes

$0.09 \mathrm{Lx} \quad$ Tooth decay

Edema in foot

Skin disease

$0.23 \mathrm{Ar}$

Hair growth

Ar, Bk Fracture

0.27 Bk, Rt Enhance breast milk

Scrape bark and apply on the stomach area

Apply on the stomach area or on the forehead

Scrape the endocarp and apply

Apply on the forehead or bath decoction

Boil and apply as hot compress; drink decoction Insert in tooth cavity

Soak in warm water and drink

Eat directly

Infuse in alcoholic gin and drink; Drink root or stem

decoction

Boil and drink decoction

Soak in water and drop into the eyes

Drop latex into the eyes or in the decaying tooth

Infused in $C$. nucifera's vinegar and apply

Boil and apply as wash

Soaked in water and bath; infused in C. Nucifera's oil and apply on the scalp

Apply scraped bark or the adventitious roots

Scrape inner bark and drink extract; rub extract on the head and on the collarbone; drink bark or root decoction

Apply on the forehead

Drink decoction

Apply on the forehead or on the stomach area alone or with M. citrifolia

Apply leaf latex

Boil with Glochodion sp. and bath decoction

Drink decoction

Crush and apply extract

$\begin{array}{lll}0.36 & \text { St } & \text { Stomachache } \\ & \text { Lf } & \text { Cuts/wounds, skin }\end{array}$

disease

disease
Sore eyes

Rt Abortifacient

0.32 Lf Vomiting blood

Vomiting blood
Cuts/wounds, skin

disease

0.36 Bk, Lf Cough, diarrhea,

stomachache

0.27 Lf Stomachache

Lf Cough

Lf Bloated stomach
Drop extract into the eyes

Drink decoction

Apply on the forehead

Chew young leaves

Boil and apply as wash

\section{Drink decoction}

Boil alone or with $C$. cainito \& $P$. dulce and drink decoction

Pound with A. catechu and apply on the stomach

Rub extract on the throat and or on chest and back of the body

Chew leaves and apply on the stomach 
Pittosporum pentandrum (Blanco) HNUL0020517 Pittosporaceae Balingkawayan 0.36 Lf, Fl Postpartum care and Merr.

Scoparia dulcis L.

Antidesma bunius (L.) Spreng.

HNUL0020539 Plantaginaceae Init-init

HNUL0020576 Phyllanthaceae Bugnay

Bischofia javanica Blume

Glochidion sp. J.R. Forst. \& G.

HNUL0020559 Phyllanthaceae To-og

HNUL0020527 Phyllanthaceae Amarugna/Maru

gna

Bambusa sp. Schreb.

HNUL0020560 Poaceae

Kawayan recovery

Cymbopogon citratus (DC.) Stapf HNUL0020610 Poaceae

Tanglad

Plagtiki

Eleusine indica (L.) Gaertn.

HNUL0020584 Poaceae

Imperata cylindrica (L.) Raeusch. HNUL0020611 Poaceae

Oryza sativa $\mathrm{L}$.

Ardisia sp. Sw.

Embelia sp. Burm.f.

HNUL0020616 Poaceae

Kogon/Tubo-

tubo

Paray

HNUL0020528 Primulaceae

Tagpo

HNUL0020556 Primulaceae

Salimawmaw

Nauclea orientalis (L.) L.

HNUL0020534 Rubiaceae

Bangkal

Morinda citrifolia $\mathrm{L}$

Uncaria sp. Schreb.

HNUL0020521 Rubiaceae

HNUL0020519 Rubiaceae

Anino

Bakan

Citrus maxima (Burm.) Merr.

HNUL0020607 Rutaceae

Kabugaw
0.18 Lf

$0.14 \mathrm{Rt}$

Cancer, UTI, vomiting

blood, intestinal cleansing

$\begin{array}{rll} & \text { Rt } & \text { Fever } \\ 0.36 & \text { Lf } & \text { Measles } \\ & & \\ & \text { Lf } & \text { Chicken pox } \\ \text { Bk } & \text { UTI }\end{array}$

Nausea, stomach ulcer recovery, fever

Postpartum care and recovery; relapse

Postpartum care and recovery

Rt, Lf Fever

0.36 Sh UTI, kidney stones,

fever

Fr Stomachache

$0.23 \mathrm{Bk}, \mathrm{Rt}$ Diarrhea, vomiting blood

0.36 St Cough

St Sore eyes

St Spasm, edema

0.23 Lf Headache

St, Bk Abortifacient

0.18 Lf Headache

Fr Cancer

Rt Karmen-karmen (amulet)

0.18 Lf Postpartum care and recovery

Lf $\quad$ Skin disease
$0.23 \mathrm{St} \quad$ Inaswang (witchcraft)
Boil with Canarium sp., J. gendarussa, C. citratus,

Glochidion sp. \& Bambusa sp. or with C. maxima and drink one glass then bath the rest

Drink decoction

Soak in water and drink; burn as incense; hang outside the door

Hang outside the doo

Drink decoction

Apply on the back and/or forehead and stomach

Drink roots or leaves decoction; Boil with Canarium sp., $P$. pentandrum, J. gendarussa, C. citratus \& Bambusa sp. and drink one glass then bath the rest

Drink decoction of flower; Boil with Canarium sp., $P$. pentandrum, J. gendarussa, C. citratus \& Glochidion sp. and drink one glass then bath the rest

Boil with Canarium sp., P. pentandrum, J. gendarussa, $C$. citratus, Bambusa sp. \& Glochidion sp. or with C. maxima and drink 1 glass then bath the rest

Infused dried roots in $C$. nucifera's oil with $P$. laevigata \&

Alpinia sp. then apply

Drink decoction

Boil with $K$. odorata \& D. triflorum and drink decoction

Boil alone or with H. riparia, M.pudica and/or $E$.

philippinensis, L. speciosa, A. muricata and drink decoction

Wrap 7 grains with $H$. suaveolens in banana leaf then heat

over the flame and apply on the stomach

Drink decoction

Drink water from the stem

Drop water from the stem into the eyes

Sliced and infused in C. nucifera vinegar and rub on the affected area

Apply young leaves on the forehead

Drink decoction

Apply with $F$. septica on the forehead and stomach

Drink decoction

Burn as incense after giving birth; place under the stairs

Slice dried roots with $M$. pruriens, A. calamus, $L$. guineensis,

$\&$ Alocasia $\mathrm{cv}$ then put in a small pouch and pin in child's

clothes

Boil with $P$. pentandrum, $C$. citratus \& Canarium sp. then drink one glass of decoction and bathe the rest

Boil and apply as wash 


\begin{tabular}{|c|c|c|c|c|c|c|c|}
\hline \multirow[t]{2}{*}{$\begin{array}{l}\text { Zanthoxylum avicennae (Lam.) } \\
\text { DC. }\end{array}$} & HNUL0020587 & Rutaceae & Salay & 0.23 & $\mathrm{Bk}, \mathrm{St}$ & $\begin{array}{l}\text { Postpartum care and } \\
\text { recovery, abortifacient }\end{array}$ & $\begin{array}{l}\text { Drink root decoction; pound stem then soak in hot water and } \\
\text { drink }\end{array}$ \\
\hline & & & & & Rt & $\begin{array}{l}\text { Stomachache, heartburn, } \\
\text { dizziness, postpartum } \\
\text { care and recovery }\end{array}$ & $\begin{array}{l}\text { Boil with A. flava, Z. avicennae \& Z. avicennae and drink } \\
\text { decoction }\end{array}$ \\
\hline \multirow[t]{4}{*}{ Chrysophyllum cainito L. } & HNUL0020566 & Sapotaceae & Star Apol & 0.5 & $\mathrm{Bk}$ & Cough & Boil with $S$. cumini and drink decoction \\
\hline & & & & & $\begin{array}{l}\text { Lf, St, } \\
\text { Bk, Rt }\end{array}$ & Diarrhea, stomachache & $\begin{array}{l}\text { Boil alone or with bark of } S . \text { cumini \& P. dulce and drink } \\
\text { decoction }\end{array}$ \\
\hline & & & & & & Pulmonary problems & Apply on the back \\
\hline & & & & & Lf, Rt & Anthelmintic & Drink decoction \\
\hline Lycopersicon esculentum Mill. & HNUL0020612 & Solanaceae & Kamatis & 0.14 & $\mathrm{Lf}$ & Stomachache & $\begin{array}{l}\text { Crushed alone or with } P \text {. angulata \& I. tinctoria then rub } \\
\text { extract }\end{array}$ \\
\hline \multirow[t]{2}{*}{ Nicotiana tabacum $\mathrm{L}$. } & HNUL0020615 & Solanaceae & Tabako & 0.14 & $\mathrm{Lf}$ & Stomachache & $\begin{array}{l}\text { Pound with } V \text {. unguiculata \& Alpinia sp. and rub on the } \\
\text { stomach area }\end{array}$ \\
\hline & & & & & $\mathrm{Lf}$ & Spasm & Infused leaf vein with $V$. trifolia in $C$. nucifera's oil and apply \\
\hline \multirow[t]{2}{*}{ Physalis angulata $\mathrm{L}$. } & HNUL0020564 & Solanaceae & $\begin{array}{l}\text { Asisi-o/Lupok- } \\
\text { lupok }\end{array}$ & 0.27 & Lf & Stomachache & $\begin{array}{l}\text { Crushed alone or with L. esculentum \& I. tinctoria then rub } \\
\text { extract }\end{array}$ \\
\hline & & & & & Lf & Diarrhea & Apply heated leaves on the stomach \\
\hline Solanum melongena $\mathrm{L}$. & HNUL0020589 & Solanaceae & Tarong & 0.23 & Lf & $\begin{array}{l}\text { Stomachache, Inaswang } \\
\text { (witchcraft) }\end{array}$ & Apply heated leaves on the stomach \\
\hline Lantana camara $\mathrm{L}$. & HNUL0020523 & Verbenaceae & Hagonoy & 0.14 & Rt & Relapse & Drink decoction \\
\hline \multirow[t]{2}{*}{ Vahl } & HNUL0020545 & Verbenaceae & Serisemento & 0.18 & Lf & $\begin{array}{l}\text { Cuts/wounds, lump, } \\
\text { black eye }\end{array}$ & Crush and apply extract \\
\hline & & & & & $\mathrm{Lf}$ & Fever & Pound and rub extract on the body \\
\hline \multirow[t]{2}{*}{ Leea guineensis G. Don } & HNUL0020535 & Vitaceae & Mamali & 0.27 & Lf & Headache, dizziness & Apply on the forehead \\
\hline & & & & & Rt & $\begin{array}{l}\text { Karmen-karmen } \\
\text { (amulet) }\end{array}$ & $\begin{array}{l}\text { Slice dried roots with Uncaria sp., A. calamus, M. pruriens, } \\
\& \text { Alocasia } \mathrm{cv} \text { then put in a small pouch and pin in child's } \\
\text { clothes }\end{array}$ \\
\hline Tetrastigma sp. Planch. & HNUL0020552 & Vitaceae & Ilahas nga layas & 0.09 & Lf & Lump & Apply on the affected area \\
\hline Aloe vera (L.) Burm.f. & HNUL0020602 & Xanthorrhoeaceae & Alobera & 0.09 & $\mathrm{Lf}$ & Hair loss & Apply fleshy leaves on the scalp \\
\hline \multirow[t]{2}{*}{ Alpinia sp. Roxb. } & HNUL0020516 & Zingiberaceae & Karupi & 0.45 & $\mathrm{Sd}$ & Skin disease & $\begin{array}{l}\text { Infused in with } P \text {. laevigata in } C \text {. nucifera and apply on the } \\
\text { affected area }\end{array}$ \\
\hline & & & & & $\mathrm{Sd}$ & Stomachache, gas pain & $\begin{array}{l}\text { Pound or chew and apply on the stomach; Pound add warm } \\
\text { water then drink; Pound with V. unguiculata \& N. tabacum } \\
\text { and rub on the stomach area }\end{array}$ \\
\hline $\begin{array}{l}\text { Etlingera philippinensis (Ridl.) } \\
\text { R.M.Sm. }\end{array}$ & HNUL0020549 & Zingiberaceae & Tagbak & 0.14 & St & $\begin{array}{l}\text { UTI, gallbladder } \\
\text { problems }\end{array}$ & $\begin{array}{l}\text { Boil with E. philippinensis, I. cylindrica, H. riparia, } L \text {. } \\
\text { speciosa \& A. muricata and drink decoction }\end{array}$ \\
\hline Zingiber officinale Roscoe & HNUL0020623 & Zingiberaceae & Luy-a & 0.09 & $\mathrm{Rh}$ & Stomachache, Gas pain & Mix with $B$. lacera and salt then apply on the stomach area \\
\hline
\end{tabular}

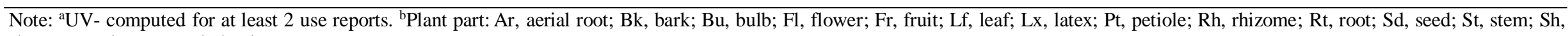
shoot; Tu, tuber; Wp, whole plant 
Table 2. Disease category, Informant Consensus Factor (ICF), and Fidelity level (FL) of frequently used medicinal plant species

\begin{tabular}{|c|c|c|c|c|c|c|c|}
\hline ICD-11 & Category name & Reported diseases or purposes & $\begin{array}{l}\text { No. of use } \\
\text { report }\end{array}$ & $\begin{array}{l}\text { No. of } \\
\text { species }\end{array}$ & ICF & $\begin{array}{l}\text { Frequently used } \\
\text { medicinal plant }\end{array}$ & $(\%) \mathrm{FL}$ \\
\hline 1 & Certain infectious or parasitic diseases & $\begin{array}{l}\text { Anti-rabies, anti-tetanus, anthelmintic, athlete's foot, chicken pox, dengue, } \\
\text { typhus, typhoid fever, measles, oral thrush, ringworm, snake bite, Tinea versicolor }\end{array}$ & 65 & 16 & 0.77 & Spondias purpurea & 100 \\
\hline 2 & Neoplasms & Cancer & 4 & 2 & 0.67 & Morinda citrifolia & 75 \\
\hline 6 & $\begin{array}{l}\text { Mental, behavioural or } \\
\text { neurodevelopmental disorders }\end{array}$ & Mental disorder & 2 & 1 & 1.00 & Donax canniformis & 50 \\
\hline 9 & Diseases of the visual system & Blurry vision, cataract, conjunctivitis, sore eyes & 20 & 6 & 0.74 & Euphorbia hirta & 69 \\
\hline 11 & Diseases of the circulatory system & Edema & 8 & 5 & 0.43 & Crinum sp. & 100 \\
\hline 12 & Diseases of the respiratory system & Cough, pulmonary problems & 63 & 18 & 0.73 & Vitex negundo & 100 \\
\hline 13 & Diseases of the digestive system & $\begin{array}{l}\text { Appendicitis, bloated stomach, constipation, diarrhea, gas pain, heartburn, } \\
\text { intestinal cleansing, nausea, gallbladder problems, liver problems, stomachache, } \\
\text { stomach ulcer, toothache, tooth decay, vomiting blood }\end{array}$ & 165 & 45 & 0.73 & Hyptis suaveolens & 100 \\
\hline 14 & Diseases of the skin & $\begin{array}{l}\text { Boil, black eye, dandruff, hair growth, hair loss, lump, pus, skin abscess, skin } \\
\text { disease, soap }\end{array}$ & 42 & 17 & 0.62 & $\begin{array}{l}\text { Tabernaemontana } \\
\text { pandacaqui }\end{array}$ & 100 \\
\hline 16 & Diseases of the genitourinary system & Kidney stones, uterine problems, urinary tract infection (UTI) & 27 & 9 & 0.69 & $\begin{array}{l}\text { Imperata cylindrical } \\
\text { Homonoia riparia }\end{array}$ & $75 / 75$ \\
\hline 18 & Pregnancy, childbirth, or the puerperium & $\begin{array}{l}\text { Abortifacient, enhance breast milk production, meconium aspiration syndrome, } \\
\text { postpartum care and recovery, promote placenta and fetus development }\end{array}$ & 72 & 21 & 0.72 & $\begin{array}{l}\text { Pittosporum } \\
\text { pentandrum }\end{array}$ & 100 \\
\hline 21 & $\begin{array}{l}\text { Symptoms, signs or clinical findings, not } \\
\text { elsewhere classified }\end{array}$ & $\begin{array}{l}\text { Dizziness, fever, headache, hiwit (sorcery), inaswang (witchcraft), karmen- } \\
\text { karmen (amulet), lump, migraine, relapse, spasm }\end{array}$ & 115 & 38 & 0.68 & Jatropha curcas & 75 \\
\hline 22 & $\begin{array}{l}\text { Injury, poisoning or certain other } \\
\text { consequences of external causes }\end{array}$ & Burn, fracture, cuts/wounds & 69 & 20 & 0.72 & $\begin{array}{l}\text { Jatropha curcas/ } \\
\text { Parameria laevigata }\end{array}$ & $75 / 100$ \\
\hline
\end{tabular}




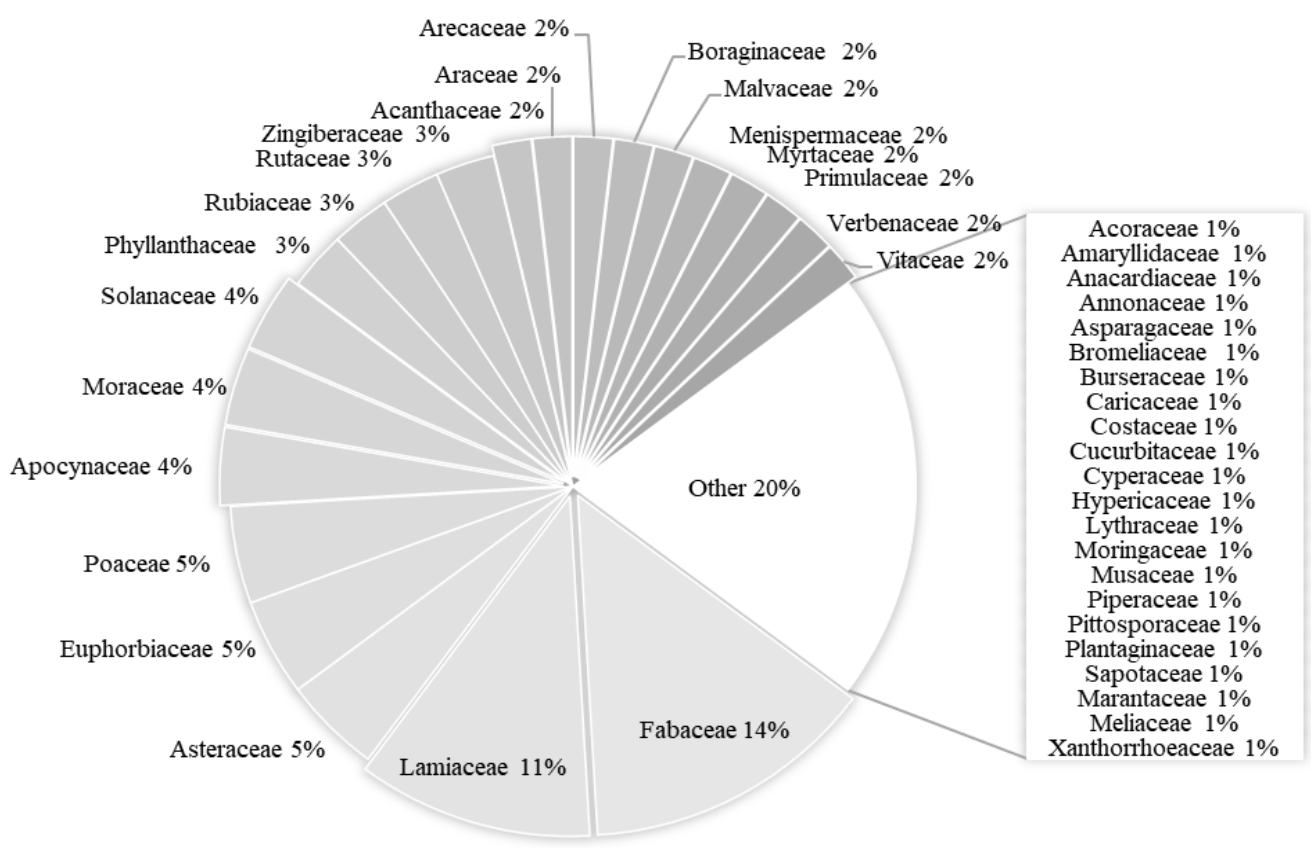

Figure 2. The percentage of medicinal plant families used by the indigenous Ati tribe in Sitio Pantad, Brgy. Igcalawagan, Tobias Fornier, Antique, Philippines

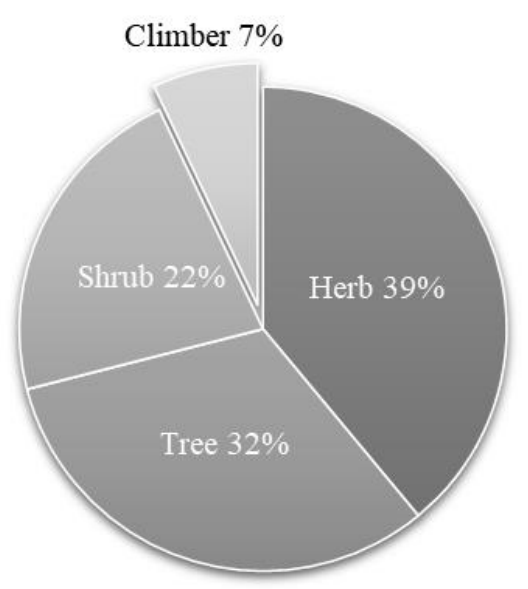

Figure 3. Medicinal plant growth habits

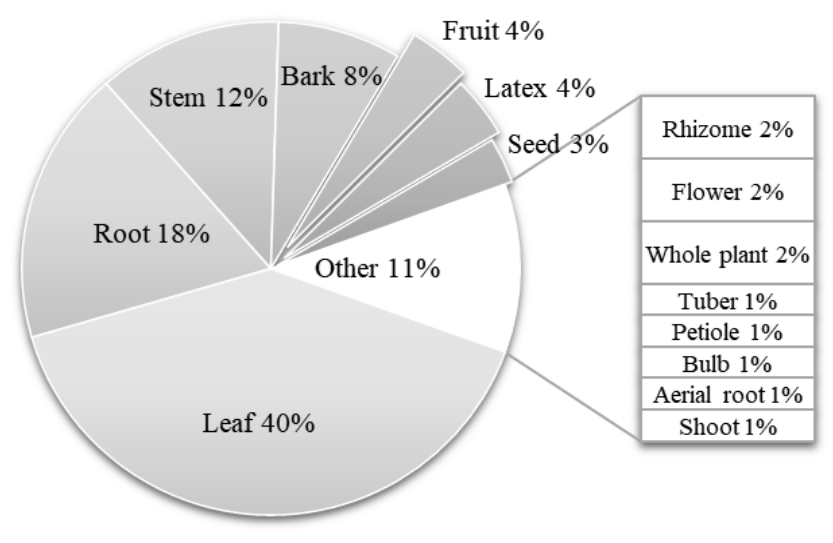

Figure 4. Plant part used for medical application or purpose

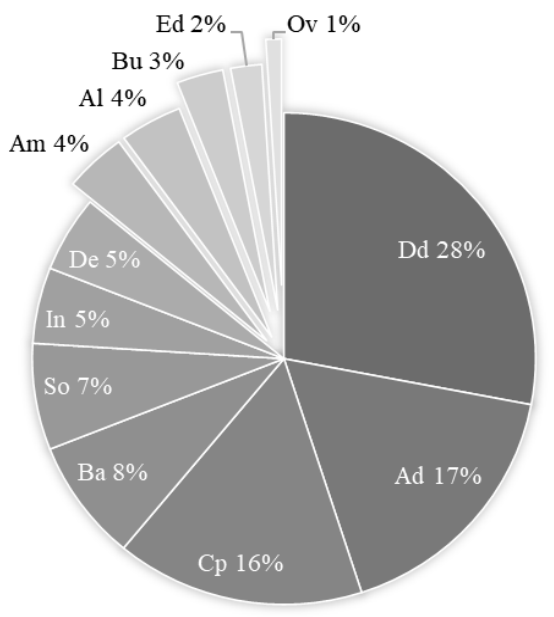

Figure 5. Preparation and administration of medicinal plants in Antique. Al, apply latex; Ad, apply part/s directly; Am, amulet and sign; $\mathrm{Ba}$, bath decoction; $\mathrm{Bu}$, burn and use ash; $\mathrm{Cp}$, crushing/pounding and apply extract; Dd, drink decoction; De, drink extract; Ed, eat, chew, and drink; In, infuse in oil or vinegar; So, soaking in water; Ov, process into oil or vinegar.

Category 13: diseases of the digestive system recorded the highest use report and highest number of medicinal plant species used. It documented 15 diseases or purpose (appendicitis, bloated stomach, constipation, diarrhea, gas pain, heartburn, intestinal cleansing, nausea, gallbladder problems, liver problems, stomachache, stomach ulcer, toothache, tooth decay, vomiting blood) and Hyptis suaveolens (L.) Poit. was frequently used species. 


\section{Fidelity level}

The FL was used to evaluate the relative importance of a medicinal plant to treat a particular disease or health problem. A high value suggested that a particular medicinal plant species were cited to treat a specific disease and were highly suggested and recommended by many informants in the tribe. Seven medicinal plants have a $100 \%$ fidelity value: $S$. purpurea for oral thrush; Crinum sp. for edema; Vitex negundo L. for cough; H. suaveolens for stomachache, bloated stomach, and diarrhea; T. pandacaqui for pus and boils; Pittosporum pentandrum (Blanco) Merr. for postpartum care and recovery; and Parameria laevigata (Juss.) Moldenke for skin disease.

\section{Discussion}

The ethnobotanical study conducted in the Ati community in Tobias Fornier, Antique showed their rich cultural and traditional practice of ethnomedicine. The documentation of 108 medicinal plant species in 44 families showcased the diverse flora of the area. Though the tribe is settled in a small community, they were able to utilize the nearby mountains and river plains for plant resources. The result of this study is a valuable contribution to the limited ethnomedicinal information used by the indigenous peoples especially in the Ati tribe in Panay Island.

The family Fabaceae were best represented with 15 medicinal plant species used in 21 different diseases or purposes across eight categories. The family is also known as Leguminosae or the bean, legume, and pea family. It is the third-largest family of flowering plants after Orchidaceae and Asteraceae and second in terms of economic and agricultural importance after Poaceae. The family is composed of about 727 genera and 19,327 widely distributed species that include numerous plants used for animal and human food, fertilizers, timber, medicines, and pharmaceuticals (Wojciechowski et al. 2006). They belong to the top five families with rich therapeutic medicinal values in rural and indigenous populations of most regions of the world. They contain variety of chemical compounds with high level of biological activity (Morales and Ladio 2012). Fabaceae were also widely utilized by other Ati (Aeta/Negrito) tribes across the country (Ong and Kim 2014; Tantengco et al. 2018; Pablo 2019).

The use of leaves as the most preferred medicinal plant part by the Ati tribe in Antique is parallel to other studies conducted in other Ati (Aeta/Negrito) communities (Ong and Kim 2014; Tantengco et al. 2018; Pablo 2019; Cordero et al. 2020) and other indigenous groups (Balangcod and Balangcod 2011; Olowa et al 2012; Abe and Ohtani 2013; Balangcod and Balangcod 2015; Balinado et al. 2017; Baddu and Ouano 2018; Dapar et al. 2020) in the country. It is the frequently used part for therapeutic use because it contains and stores secondary metabolites that can inhibit microbial growth in different ways and can break down cellular membrane in microorganisms (Chanda and Kaneria 2011). According to phytochemical and pharmacological studies, leaves showed the highest antioxidant property, maximum antibiotic activity, and anti-diabetic potential as compared to other parts in various medicinal plants (Jain et al. 2019). In a tropical country like the Philippines, leaves can be harvested all year round and readily available and accessible when needed for medicinal purposes compare to other plant parts.

The Ati tribe used decoction for drinking, bathing for mothers after giving birth, sponge bath for infants and children, and apply as wash for cuts, wounds, and skin disease. The decoction of polyherbal in traditional medicine is very evident in rural (Balinado and Chan 2017) and indigenous groups in the country (Ong and Kim 2014; Cordero et al. 2020). In Chinese (Yang and Ross 2010) and Ayurvedic herbal medicine (Verma et al. 2016), decoction is also the most common form of preparation and usually taken orally. In Chinese medicine, it is prepared by placing the dried medicinal plants in a ceramic pot with water that is $3-4 \mathrm{~cm}$ above the herbs and soaked for an hour. The herbs are boiled and simmer for 20 minutes then the decoction is strained. Boil the herbs for the second time with less water, then combine the decoctions, and divided them into twothree doses. The absorption and effectivity of drinking decoction are much higher than that of other traditional types of preparation. It is usually used for more serious and severe diseases and conditions. It can also be used topically as bath for the whole body or for the affected parts of the body (Yang and Ross 2010).

Euphorbia hirta had the highest use value indicated by the highest number of users report from the informants. It is normally used for visual problems, dengue, typhoid, and headache by the Ati people. It is used in ethnopharmacology worldwide for gastrointestinal disorders, bronchial and respiratory diseases, and visual illness. It also shows antibiotic, anti-inflammatory, anticancer, antioxidant, antifertility, and antigalactogenic properties (Kumar et al. 2010). In the Philippines, it's been used in folk medicine to treat cataract (Madulid et al. 1989), skin disease (Tantiado 2012), arthritis, dislocation/ fracture, sprain (Abe and Ohtani 2013), fever (Ragragio et al. 2013), sore eyes, cuts and wounds (Ong and Kim 2014), dengue (de Guzman et al. 2016).

Plants with the highest UV and FL were $S$. purpurea for oral thrush, T. pandacaqui for skin problems (pus, boil, skin diseases), and $H$. suaveolens for digestive system disorders (stomachache, diarrhea, bloated stomach). $S$. purpurea has bioactive compounds with antioxidant and antiulcer properties (de Almeida et al. 2017) and used traditionally for gastric disorders, diabetes, and cholesterol (Marisco and Pungartnik 2015). H. suaveolens contains phytochemicals such as alkaloids, flavonoids, terpenoids, and tannins with antioxidant, antimicrobial, anthelmintic, anti-inflammatory, antidiabetic, and wound healing activities (Ngozi et al. 2014). T. pandacaqui contains alkaloids that have anti-inflammatory, antipyretic and antinociceptive activities (Taesotikul et al. 2003).

The documentation of the medicinal plants used by the indigenous Ati tribe is an important contribution to the limited information of the traditional and complementary alternative medicine in Panay Island and in Western Visayas. The medicinal practice and tradition they used were greatly influenced by their culture and religious beliefs. The result of this study serves as an ethnobotanical base for drug 
research and formulation and as awareness for preserving ethnomedicine as a safe and effective alternative means in the health care delivery system.

\section{ACKNOWLEDGEMENTS}

The authors would like to thank the Ati Tribe members of Sitio Pantad for sharing their ethnobotanical knowledge and practices and for welcoming and accommodating the first author during her stay in the community. Grateful appreciation is also given to the NCIP-ACSC and NCIP Region VI/VII officers for the issuance of the Certification Precondition (R6-2019-04-028) and to the DENR-Region VI for the Wildlife gratuitous permit. The first author would like to thank the Commission on Higher EducationScholarship for Graduate Studies Local (K-12) for the scholarship.

\section{REFERENCES}

Abe R, Ohtani K. 2013. An ethnobotanical study of medicinal plants and traditional therapies on Batan Island, the Philippines. J Ethnopharmacol 145 (2): 554-65.

Baddu V, Ouano N. 2018. Ethnobotanical survey of medicinal plants used by the Y'Apayaos of Sta. Praxedes in the Province of Cagayan, Philippines. Mindanao J Sci Technol 16: 128-153.

Balinado L, Chan M. 2017. An ethnomedicinal study of plants and traditional health care practices in District 7, Cavite, Philippines. International Conference on Chemical, Agricultural, Biological and Medical Sciences (CABMS-17) Manila, Philippines, January 23-24 2017.

Balangcod T, Balangcod AK. 2011. Ethnomedical knowledge of plants and healthcare practices among the Kalanguya tribe in Tinoc, Ifugao, Luzon, Philippines. Indian J Tradit Knowl 10 (2): 227-238.

Balangcod T, Balangcod K. 2015. Ethnomedicinal plants in Bayabas, Sablan, Benguet Province, Luzon, Philippines. E J Biol 11 (3): 63-73.

Beyer O. 1917. Population of the Philippine islands in 1916 (población de las islas Filipinas en 1916) prepared under the direction of, preparado bajo la dirección de H. Otley Beyer. Philippine Education Co. Inc., Manila, Philippines.

CBD. 2019. Philippines: The 6th National Report to the Convention on Biological Diversity. Convention on Biological Diversity. https://asean.chm-cbd.net/sites/test-acb/files/2020-04/6NR_PHL.pdf

Chanda S, Kaneria M. 2011. Indian nutraceutical plant leaves as a potential source of natural antimicrobial agents. Vilas $M$ (ed.) Science against Microbial Pathogens: Communicating Current Research And Technological Advances. Formatex Research Center, Badajoz, Spain.

Cordero C, Ligsay A, Alejandro GJD. 2020. Ethnobotanical documentation of medicinal plants used by the Ati tribe in Malay, Aklan, Philippines. J Complement Med Res 11 (1): 170-198.

Dapar ML, Alejandro GJD, Meve U, Liede-Schumann S. 2020. Quantitative ethnopharmacological documentation and molecular confirmation of medicinal plants used by the Manobo tribe of Agusan del Sur, Philippines. J Ethnobiol Ethnomed 16 (14): 1-60.

de Almeida CL, Brito S, De Santana T, Costa HB, Carvalho Jr. CH, da Silva M, de Almeida LL, Rolim LA, dos Santos VL, Wanderley AG, da Silva TG. 2017. Spondias purpurea L. (Anacardiaceae): Antioxidant and antiulcer activities of the leaf hexane extract. Oxid Med Cell Longev. DOI:10.1155/2017/6593073.

de Guzman G, Dacanay A, Andanay B, Alejandro GJD. 2016. Ethnopharmacological studies on the uses of Euphorbia hirta in the treatment of dengue in selected indigenous communities in Pangasinan (Philippines). J Intercult Ethnopharmacol 5 (3): 239-243.

de la Peña LC. 2009. The power to influence and to protect: interconnectedness of the human bodies. Liceo J Higher Educ Res 6 (1): $25-36$
DIVA-GIS. 2012. Version 7.5 Free Spatial Data by Country. https://www.diva-gis.org/

Eberhard D, Simons G, Fennig C. 2020. Ethnologue: Languages of the World (23rd ed) Dallas, Texas: SIL International. http://www.ethnologue.com

Friedman J, Yaniv Z, Dafni A, Palewitch D. 1986. A preliminary classification of the healing potential of medicinal plants, based on a rational analysis of an ethnopharmacological field survey among Bedouins in the Negev Desert, Israel. J Ethnopharmacol 16: 275-287

Fornier J. 1998. Economic developments in Antique Province: 1800-1850. Philipp Stud 46 (4): 407-428.

Headland T. 1987. Negrito Religions: Negritos of the Philippine Islands. In: Eliade M (ed.). The Encyclopedia of Religion 10. Macmillan, New York.

Heinrich M, Ankli A, Frei B, Weimann C, Sticher O. 1998. Medicinal plants in Mexico: Healers' consensus and cultural importance. Soc Sci Med 47 (11): 1859-1871.

Jain C, Khatan S, Vijayvergia R. 2019. Bioactivity of secondary metabolites of various plants: a review. Int J Pharm Sci Res 10 (2): 494-504.

Kumar S, Malhotra R, Kumar D. 2010. Euphorbia hirta: Its chemistry, traditional and medicinal uses, and pharmacological activities. Pharmacogn Rev 4 (7): 58-61.

Longuefosse JL, Nossin E. 1996. Medical ethnobotany survey in Martinique. J Ethnopharmacol 53 (3): 117-142.

Madulid DA, Gaerlan FJM, Romero EM, Agoo EMG. 1989. Ethnopharmacological study of the Ati tribe in Nagpana, Barotac Viejo, Iloilo. Acta Manil 38: 25-40.

Marisco G, Pungartnik C. 2015. Spondias purpurea L. (Anacardiaceae): Traditional uses, chemical composition and biological activities. Sci Amazon 4 (2): 10-18.

Morales S, Ladio A. 2012. The usefulness of edible and medicinal Fabaceae in Argentine and Chilean Patagonia: Environmental availability and other sources of supply. J Evid Based Compl Altern Med. DOI: 10.1155/2012/901918.

NCIP. 2019. Community Population (Census) Province of Antique. National Commission on Indigenous Peoples Antique/Aklan Community Service Center. San Jose Buenavista, Antique.

Ngozi U, Ugochukwo N, Ifeoma U, Charity A, Chinyelu E. 2014. The efficacy of Hyptis suaveolens: A review of its nutritional and medicinal applications. Euro J Med Plants 4 (6): 661-674.

NEDA. 2017. Philippine Development Plan 2017-2022. National Economic and Development Authority. http://pdp.neda.gov.ph/

Olowa L, Torres MA, Aranico E, Demayo C. 2012. Medicinal plants used by the Higaonon Tribe of Rogongon, Iligan City, Mindanao, Philippines. Adv Environ Biol 6 (4): 1442-1449.

Ong HG, Kim YD. 2014. Quantitative ethnobotanical study of the medicinal plants used by the Ati Negrito indigenous group in Guimaras Island, Philippines. J Ethnopharmacol 157: 228-242.

Ong P, Afuang L, Rosell-Ambal RG. 2002. Philippine Biodiversity Conservation Priorities: A Second Iteration of the National Biodiversity Strategy and Action Plan. Department of Environment and Natural Resources-Protected Areas and Wildlife Bureau, Conservation International Philippines, Biodiversity Conservation Program. University of the Philippines Center for Integrative and Development Studies, and Foundation for the Philippine Environment, Quezon City, Philippines.

Pablo CG. 2019. Botika sa Kalikasan: Medicinal plants used by Aetas of Sitio Parapal Hermosa Bataan, Philippines. J Soc Health 2 (1): 101127.

Padilla Jr. S. 2013. Anthropology and GIS: Temporal and spatial distribution of the Philippine Negrito groups. Hum Biol 85 (1): 20930.

PCHRD. 2013. Philippine Council from Health Research and Development. 2013. Elderly in indigenous people communities need medical service at home, study affirms. Philippine Council from Health Research and Development. Department of Science and Technology. http://www.pchrd.dost.gov.ph/

Pelser P, Barcelona J, Nickrent D. 2011. Co's Digital Flora of the Philippines. www.philippineplants.org

Phillips O, Gentry A. 1993. The useful plants of Tambopata, Peru: I. Statistical hypotheses tests with a new quantitative technique. Econ Bot 47 (1): 15-32.

POWO. 2019. Plants of the World Online. Facilitated by the Royal Botanic Gardens, Kew. http://www.plantsoftheworldonline.org/ 
Ragragio E, Zayas CN, Obico JJ. 2013. Useful plants of selected Ayta communities from Porac, Pampanga, Twenty years after the eruption of Mt. Pinatubo. Philipp J Sci 142 (3): 169-181.

Rahmann R, Maceda M. 1958. Some notes on the Negritos of Iloilo, Island of Panay, Philippines. Anthropos 53: 864-876.

Rahmann R, Maceda M. 1962. Notes on the Negritos of Antique, Island of Panay, Philippines. Anthropos 57 (3/6): 626-643.

Stuartxchange. 2019. Lists of Philippine Herbal Medicinal Plants. http://www.stuartxchange.org/CompleteList. html

Tantengco OA, Condes ML, Estadilla HH, Ragragio E. 2018. Ethnobotanical survey of medicinal plants used by Ayta Communities in Dinalupihan, Bataan, Philippines. Pharmacog J 10 (5): 859-70.

Tantiado R. 2012. Survey on Ethnopharmacology of Medicinal Plants in Iloilo, Philippines. Inter J Bio Sci BioTech 4 (4): 11-26.

Taesotikul T, Panthong A, Kanjanapothi D, Verpoorter R, Scheffer JJ. 2003. Anti-inflammatory, antipyretic and antinociceptive activities of Tabernaemontana pandacaqui Poir. J Ethnopharmacol 84 (1): 31-35.

The Plant List. 2013. Version 1.1. http://www.theplantlist.org

Tropicos. 2019. Missouri Botanical Garden. http://www.tropicos.org

UNDP. 2010. Fast Facts: Indigenous Peoples in the Philippines. United Nations Development Programme. http://www.ph.undp.org/
Verma A, Janani H, Yadav S, Galib R. Prajapati PK. 2016. Pharmaceutical and analytical studies on Guduchi Kwatha prepared by varying proportions of water. J Ayu Herb Med 2 (4): 125-130.

Worcester D. 1913. The Non-Christian Peoples of the Philippines Islands. The National Geographic Magazine 24 (11). National Geographic Society, Washington, D.C.

WHO. 2020. ICD-11 for Mortality and Morbidity Statistics Version: 09/2020. World Health https://icd.who.int/browse11/1-m/en

Wojciechowski M, Mahn J, Jones B. 2006. Fabaceae. Legumes Version 14. The Tree of Life Web Project. http://tolweb.org/

WFO. 2019. World Flora Online. http://www.worldfloraonline

Yang Y, Ross J. 2010. Theories and Concepts in the Composition of Chinese Herbal Formulas. Chinese Herbal Formulas. Churchill Livingstone, Edinburgh.

Zayas CN. 2008. Trade and patronage of Ati materia medica in the Visayas. In: Paz CJ (ed) Ginhawa, Kapalaran, Dalamhati (Essays on Well-being, Opportunity/Destiny and Anguish). University of the Philippines Press, Quezon City. 